\title{
"Are you so ashamed to come from Poland and to speak your mother tongue?" - metalinguistic talk, identities and language ideologies in teenagers' interactions on ASKfm
}

\author{
Maria Antonina Obojska \\ University of Oslo, Centre for Multilingualism in Society \\ across the Lifespan
}

Correspondence to: m.a.obojska@iln.uio.no

'The capacity to live with difference is, in my view, the coming question of the 21 st century' (Stuart Hall).

\begin{abstract}
This article applies the concept of metasociolinguistic stance specifically to investigate and analyse how identities and competing discourses can be (re)constructed in metalinguistic talk. In particular, the article analyses how stancetaking can serve as a vessel for constructing language ideologies and identities in metalinguistic talk between a Polish teenager based in Norway and her followers on a social media platform. Inspired by online ethnography, this study combines the observation of online activities, the analysis of screendata, as well as data obtained through direct online and offline discussions with the profile owner. The study showed that the focal participant and her predominantly Polish followers took different metasociolinguistic stances towards the use of Polish and Norwegian in communication between people of Polish origin. While the homeland-based followers constructed an indexical link between ethnic origins and obligatory practice of speaking Polish, the focal participant contested these ideological assumptions and oriented towards a more flexible understanding of the relationship between language and belonging. This contribution shows how social media can serve as a rich research site where the members of diasporic communities and the members of the homeland societies come into contact and interact with each other bringing in different discourses and ideologies into the conversations.
\end{abstract}

Key words: ASKfm, adolescents, Polish, Norwegian, metasociolinguistic stance, language ideologies 


\section{INTRODUCTION}

T he aim of this article is to investigate the co-construction of language ideologies, identities and stances in online metalinguistic talk by a Polish teenager living in Norway and her followers. The concept of stance has been found to be pivotal for understanding how identities are constructed (Barton \& Lee, 2013; Jaffe, 2009; Johnstone, 2009; Vandergriff, 2016), both in offline and online settings. In this paper, stance is understood as a three-fold act in which the speakers evaluate stance objects, position themselves and others and align to varying degrees of convergence with their interactants (cf. Du Bois, 2007). Social media offers a particularly stancerich environment in which users are invited and expected to orient towards the posted content through 'liking', 'sharing', overt commentaries and the use of emoticons (Vandergriff, 2016).

This paper focuses on the coconstructions of stances towards language practices online between a Polish adolescent girl living in Norway and her followers based in Poland. The Poles are at the moment the biggest immigrant group in Norway (Statistics Norway, 2016). The exact number of children in this group is unknown, however, Poland has been reported to be the top country for family reunifications in Norway since 2006 (Bell \& Erdal, 2015; Slany \& Strzemecka, 2015) and, in addition, solely the number of Norwegians born to Polish parents amounted to 11052 at the beginning of 2017. Taking this into consideration, we may be dealing with a potentially big group of children who are largely invisible in public records and in research (cf. Wærdahl, 2016). Polish children in Norway remain also a highly under- researched group from a sociolinguistic perspective (cf. Bygdås,
2016) and little is known about their language practices, language ideologies and identity constructions.

The body of research on stancetaking online has been continuously growing in recent years. For example, Myers (2010) found that stancetaking on blogs served rather as a means of selfpositioning than a way of contributing to the public debate. Walton \& Jaffe (2011) investigated the role racialized stances produced by a blog author and his commentators played in simultaneously parodying the privileged class habitus and participating in it. Chun \& Walters (2011) found that the participatory character of YouTube, on the one hand, enabled a stand-up comedian and his audience to produce a collective positive stance towards Arabness and, on the other hand, instantiated essentialised a racist ideologies of Orientalism. Barton and Lee (2013) investigated how different semiotic modes and writing spaces work together in multimodal stancetaking acts on flickr. Vandergriff (2016) pointed out that stancetaking online enabled users of reddit to successfully construct L2 selves and negotiate a supportive space. To the best of my knowledge, however, no studies up till now have explored the ASKfm platform as a research site.

In this context, the present casestudy explores language ideologies and identities co-constructed online by a Polish adolescent girl living in Norway and her followers through taking stance towards the teenager's language practices. The two main questions tackled in this article are: 1 . how do participants in online interactions evaluate the use of Polish and Norwegian by Polish teenagers living in Norway? 2. How do the interactants position themselves and others when engaging in metalinguistic talk online? Through qualitative analysis of Computer Mediated Communication 
(CMC) data drawn from a social media profile on ASKfm platform, this article explores the nexus of identities, stances and language ideologies in order to shed light on how, through talking about language, the interactants construct, ascribe and reject identities, as well as align with and contest larger societal discourses.

\section{THEORETICAL}

\section{BACKGROUND: STANCE, IDENTITY AND LANGUAGE IDEOLOGIES}

In my analysis I use the concept of stancetaking, defined by $\mathrm{Du}$ Bois (2007) as 'a public act by a social actor, achieved dialogically through overt communicative means, of simultaneously evaluating objects, positioning subjects (self and others), and aligning with other subjects, with respect to any salient dimension of the sociocultural field' [163]. According to this model, stance is a three-dimensional act in which speakers, through expressing judgments about stance objects (the referential targets of the utterance), say something about themselves and their relationship to the world (positioning of the self), and by doing so affect the subject positions of their interlocutors (positioning of the others) and simultaneously orient with different degrees of convergence towards previous utterances (alignment). I analyse stance as grammatically and lexically encoded through for example affect markers (which include adverbs, verbs and adjectives), hedges, emphatics and modals (cf. Biber \& Finegan, 2009).

When speakers display 'an attitude or position with respect to language hierarchies and ideologies' or towards the assumed connections between language and identity, they engage in the construction of what Jaffe (2009:17) refers to as the metasociolinguistic stance. As Jaffe (2009) notes, metasociolinguistic stances may be expressed through various means, for example through patterns of form or code choice (e.g. choosing a more prestigious variety over the less prestigious one), through speakers' self-conscious displays of consistency or inconsistency in using specific forms or codes, or through overt alignment with particular language ideologies expressed in overt commentary (cf. Johnstone, 2009). Language ideologies are understood here after Kroskrity (2010) as cluster concepts encompassing the multiplicity of 'beliefs, feelings, and conceptions about language structure and use which often index the political economic interests of individual speakers, ethnic and other interest groups and nation states' [192].

According to Barton \& Lee (2013), through stance-taking the interactants may attempt to convey a particular 'sense of self' [31, 87] and, thus, investigating acts of stance may enhance the understanding of how identities are constructed and negotiated both online and offline. In this paper, I take a social constructionist view on identity, which sees identities as 'constructed, validated, and offered through discourses available to individuals at a particular point in time and place' (Pavlenko \& Blackledge, 2004:14). In this approach the relationship between language and identity is twofold: firstly, discourses provide the terms and linguistic means of identity construction and negotiation, secondly, ideologies of language and identity influence the individuals' use of linguistic means of identity construction and their evaluation of linguistic resources employed by others (ibidem). This duality points to the discursive embeddedness 
of identities and to their intersections with ideologies. Following Thurlow \& Jaworski (2009), I argue that the concept of stancetaking may be particularly fruitful for examining the relations between identities and ideologies, as the evaluation of objects in stancetaking acts often instantiates ideologies and at the same time serves the purposes of self and other identification. Through stancetaking speakers may activate and actualize certain aspects of social and linguistic ideologies and by doing so in an implicit and covert way, they may naturalize the said ideologies. Jaffe (2009) argues that when ideologies are not overtly expressed but rather implied, they are constructed as non-questionable and thus they may instantiate direct links between linguistic resources (such as specific forms, languages and ways of speaking) and the social meaning in the process of iconisation (cf. Gal \& Irvine, 2000).

\section{RESEARCH SITE, METHOD, DATA AND PARTICIPANTS}

ASKfm is a social-networking platform built on a Q\&A format available both as a website and as a mobile app. The platform has a simple design and it does not allow for extensive self-presentations by the profile owner. The main part of the interface is a wall where questions and answers are posted. The questions can be asked both by anonymous or registered users but, nevertheless, it is the profile owner who has the control of what gets posted, as all unanswered questions remain hidden from the wall. Another important characteristic of ASKfm is that the profiles are rarely stand-alone ones, instead, they are mostly linked to the profile owner's accounts on other social media platforms, such as Instagram,
YouTube, Facebook, etc. This particular format creates an interactional space in which both registered and anonymous followers can actively inquire about, comment on, evaluate and challenge posts shared by the profile owner across the different social media platforms. It is these affordances of ASKfm that create a stance-rich environment (Jones et al., 2011), in which information exchange, as well as knowledge and opinion sharing are not only encouraged but also expected.

This case study emerged as part of a larger research project examining language ideologies, practices and identity constructions of Polish immigrants in Norway. The focal participant, Ana, was recruited through snowball sampling (Hoffman, 2013). The initial contact was made via sms and later on was continued through Facebook instant messaging, phone calls, text messages and faceto-face meetings. Ana is a 17 year-old Polish girl who had been living with her family in a small town in Norway since the age of nine. She considers herself to be fluent in Polish, Norwegian and English and has some competence in German and Spanish. Polish is the main language used by her family at home, however, Ana uses predominantly Norwegian when communicating with her friends. Ana is active on many socialmedia platforms: she has Facebook, Instagram and Snapchat accounts and her own YouTube channel (followed by 3690 subscribers), where she shares clips with various contents, ranging from fashion and makeup tips, through travel vlogs to Q\&A on life in Norway. Ana's YouTube channel is intended for a Polish audience and, accordingly, the clips are predominantly in Polish, with occasional instances of (subtitled) content in English, Norwegian and Spanish. Ana's followers have the opportunity to get 
to know her better through an ASKfm account which is linked to her YouTube channel. According to Ana's own reports, the majority of her followers are Polish teenagers living in Poland and thus most of the content on her ASKfm profile is also in Polish. (Nevertheless, instances of conversations in English and Norwegian occur, as well as infrequent lexical elements from other languages).

The study was inspired by the online ethnography approach (Androutsopoulos, 2008, 2015) and combined observations of online activities on the profile of the focal participant, collection and analysis of both screen data and data obtained through direct online and offline contact with the participant. The participant gave informed, written consent to participate in the study and was made aware of the possibility to withdraw from participation at any time. In total, I collected 1483 screenshots (data units) which encompasses three years of activity on Ana's ASKfm profile. Each screenshot consists of a question asked by a follower and the profile owner's response. Out of the 1483 data units, 60 screenshots referred to language use, norms and forms and all together were categorized as metalinguistic talk. These 60 data units formed together 47 conversations (as some conversation consisted of more than just one question and answer). Subsequently, the 47 conversations were coded, quantified and grouped into nine mutually non-exclusive themes: Norwegian (12 instances in the data set), English (3), Polish (3), Language practices (15), Language advice (5), Language learning (3), and Language competence (11). While the total of data units containing metalinguistic talk might not be striking, it does, nevertheless, constitute roughly $4 \%$ of all the conversations on the profile, which, given the age-group and general topics of interest of the profile owner and her followers, seems to be quite a considerable number.

\section{METALANGUAGE ON ANA'S ASKFM PROFILE: COMPETING LANGUAGE IDEOLOGIES AND IDENTITY NEGOTIATIONS}

Although metalinguistic talk on Ana's ASKfm profile is diverse and includes instances of conversations related to language forms and structures, language learning, and language competence, the most prominent topic was by far Ana's language practices, with 15 instances of data units related to this subject. In the remaining part of this section I analyse two excerpts of conversations between Ana and anonymous followers, in which the interactants take metasociolinguistic stance towards Ana's language practice of speaking Norwegian with other Polish girls living in Norway, a topic that caused considerable upheaval amongst Ana's followers. In particular, I look at how the interactants, in talking about observed language practices, (re)construct language ideologies, position themselves and each other reflexively and engage in acts of alignment (cf. Du Bois, 2007).

\section{Ashamed to be Polish}

In the excerpt below the stance object is Ana's practice of using Norwegian in communication with Viola - another Polish girl living in Norway who is also a participant in my larger research project. Viola and Ana are friends and are similar in many respects: both of them are 17 , both moved to Norway at the age of 9, both live with two Polish caregivers and younger siblings, both are active on social 
media platforms and both speak Polish at home. The girls report speaking and writing Norwegian between themselves. Indeed, the practice of communicating in Norwegian can also be observed across the girls' social media platforms, where they comment on each other's posts, clips and pictures. The followers' question was sparked by a screenshot of a Facebook conversation between Ana and Viola which was shared on Ana's ASKfm profile.

\section{Excerpt 1}

1 Follower: Dlaczego z viola rozmawiasz po norwesku? tak bardzo się wtydzicie why do you speak Norwegian to viola? are you so ashamed

2 tego, że pochodzicie z Polski i rozmawiacie w ojczystym języku? to come from Poland and to speak your mother tongue?

3 Ana: nigdy w życiu, po norwesku rozmawiamy bo łatwiej no way [never in my life], we speak Norwegian because it is easier

4 jest nam dobrać stowa, po polsku tė̇ rozmawiamy...Nawet jak nie chcemy for us to find words, we speak Polish, too...Even when we don't want

5 zeby ktoś rozumiat kto jest Norwegiem to po polsku gadamy haha somebody who is Norwegian to understand, then we chat in Polish haha

In lines 1 and 2 , the anonymous follower disaligns with Ana and Viola's practice of communicating in Norwegian. Speaking Norwegian between Polish people is challenged and implicitly negatively evaluated by the follower through the ascription of the feelings of shame as the possible underlying cause of the observed practice. By suggesting that Ana and Viola are ashamed due to their nationality and mother-tongue and fortifying the adjective by the adverb 'so', the follower implicitly accuses them of displaying a lack of national pride and respect for the Polish language. Indirectly she questions Ana and Viola's patriotism, which is a value highly regarded, relevant and widely discussed in Poland (cf. Cieśla, 2012; Leszczyński, 2016; Newsweek Polska, 2014). It can be inferred from this criticism that the underlying assumption is that Polish people should speak Polish, which echoes the one nation one language ideology (Woolard, 1998:16). It is also worth noting that the follower explicitly invokes the notion of the mother tongue (język ojczysty), which in Polish is heavily laden and carries patriotic connotations stemming from the times of prolonged occupations and partitions of the country (cf. Chłopicki, 2005; Duszak, 2006). Through challenging Ana and Viola's language practices, the follower constructs two opposite identities: a proud, patriotic Pole who respects the country of origin and the mother tongue and a Pole who is ashamed of the own background and of the mother tongue. The follower positions Ana and Viola as the latter and herself speaks, presumably, from the former position. The follower's patriotic orientation also seems to be reflected in the particular capitalization convention of her post: the only capitalized word in her turn is 'Poland', which could be read as an expression of respect for the country of origin. Other proper names and beginning of the sentences lack capitalization, contrary to standard Polish spelling conventions. 
Interestingly, in response to the rather face-threatening questions (Brown \& Levinson, 1987:65) of the follower, in lines 3 to 5 Ana chooses to defend herself and explain her language practices. She does not question the legitimacy of the follower's questions and comments regarding her language use, nor does she challenge the follower's assumption regarding 'appropriate' language practices between people of Polish origin. In her answer, she disaligns with the follower and rejects the ascribed position of a person ashamed of her origins by using the exclamative 'no way' (nigdy w życiu) in line 3 and assuring in an affirmative sentence in line 4 that she and Viola do speak Polish together, too. She goes on to explain her language practices with practical reasons such as ease of communication ('it is easier for us to find words'). In other words, Ana evaluates the language practice of speaking Norwegian as neutral and natural. Moreover, she attempts to create affiliation with the follower by reporting on the use of Polish between herself and Viola and by constructing Polish as a 'secret', common code for Poles in lines 4 and 5. In her account, Ana also constructs two categories: 'us' - people who have competence in Polish, and 'them' (e.g. Norwegians) - who do not have any competence in Polish and who can be excluded if the in-groups so wish ('when we don't want somebody who is Norwegian to understand, then we speak Polish haha'). This is achieved by the use of 1 st person plural verbs rozmawiamy, nie chcemy, gadamy ('we talk', 'we don't want', 'we chat') to index the in-group members, who have skills in Polish, and through the use of the indefinite pronoun ktoś ('somebody') modified by the relative clause specifically labelling the person as 'Norwegian' to indicate the out-groups. She frames her statement as a jocular, light-hearted utterance by ending it with the representation of laughter. However, the Polish syntactic construction with the multiple embedded clauses used by Ana seems rather heavy and 'clumsy'. As Bonilla-Silva (2002) notes, grammatical mistakes, hesitations and incoherence become more frequent when speakers discuss sensitive subjects. Given Ana's overall high proficiency in Polish, not only witnessed by the researcher but also attested by her top marks in both oral and written parts of an exam in Polish she recently took, Ana's use of clumsy syntactic structure to other the outgroup, i.e. Norwegians, may indicate some inner strugglel. It can be inferred from Ana's words that the in-groups, i.e. people having competence in Polish are not bound to speak it at all times and are free to use other linguistic resources, also in communication with other ingroups. In Ana's account ethnicity does not index normative language practices. By orienting towards maximizing the ease and efficiency of communication and permitting herself and others to engage in meaning making through the use of other linguistic resources (e.g. Norwegian), Ana constructs a flexible, multilingual identity for herself, which stands in a clear opposition to the binary identity categories constructed by her follower.

1 Ana's boyfriend is Norwegian and so are most of her friends. In the interview she stated clearly that she does not identify much with Polish teenagers living in Norway and that she does not feel different from her Norwegian peers. 


\section{Excerpt 2:}

1. Follower: Czemu piszesz z viola po norwesku? Why do you write [singular] to viola in Norwegian?

2. Ana: Bo tak nam wygodniej do polskiej szkoly

Because it is more convenient for us, we didn't go to the Polish school

3. prawie nie chodzilysmy i tak samo przychodzi almost at all and it just happens like this

4. Follower: A rozmawiacie tez po norwesku? Do you also speak [plural] Norwegian [to each other]?

5. Ana: Tak Yes

6. Ana: Wiecie co? Jeszcze 5 minut temu bylam strasznie szczesliwa... You know [plural] what? 5 minutes ago I was incredibly happy...

7. A teraz chce mi się ryczeć, wohoo my life is amazing and now I feel like crying, wohoo my life is amazing

8. Follower: Polki gadaja do siebie po norwesku... Fuck logic Polish girls speak Norwegian to each other... Fuck logic

9. Ana: Norweski umiemy tez lepiej niz polski We also know Norwegian better than Polish

10 Fuck it all Fuck it all

\section{Fuck logic}

Similarly to excerpt 1 , in excerpt 2 an anonymous follower asks Ana about her practice of using Norwegian when communicating with Viola. On the surface it might seem that the conversation is about speaking Norwegian but it turns out that the interactants are talking about not speaking Polish.

The follower's initial question in line 1 sets Ana and Viola's practice of writing in Norwegian to each other as the stance object. The question is immediately understood by Ana not as a genuine inquiry about her use of Norwegian when writing to Viola but as a question challenging her language practices. Again, Ana does not question the legitimacy of the question, nor its underlying assumptions. Instead, in lines 2 and 3 , she chooses to justify her and Viola's practices. In Ana's answer, we observe a pronominal switch: the follower used the second person singular in his question, Ana answers in first person plural. This move can be seen as a strategy deemphasizing her responsibility, strengthening the collective agency and legitimizing her practice as a generalizable one (De Fina, 2003). Using the adverb of manner wygodniej Ana explicitly evaluates the use of Norwegian as 'more convenient' and makes an implicit link between this practice, her experienced ease of using Norwegian and the lack of formal schooling in Polish ('we didn't go to the Polish school almost at all'). Furthermore, Ana attempts to normalize the practice of using Norwegian by stating that 'it just happens like this'.

In the next turn in line 4, the follower pursues the topic further and 
sets the practice of speaking Norwegian as the stance object. Ana still does not question the legitimacy of the question, however she indicates that she would prefer to change the subject: she confirms the practice of speaking Norwegian to Viola with the affirmative 'yes' in line 5 and continues her turn in a new line (6) attempting to switch the stance object by commenting on her mood swings and, this time, addressing a larger audience by using the discourse marker 'you know what' (wiecie co) in second person plural. She ends her turn with an auto-ironic phrase in English: 'wohooo my life is amazing', which could either be read as an attempt to change the language of the conversation or as a discursive device stressing the wish of changing the topic of the conversation and the interlocutor. All these moves suggest Ana's divergent alignment with the follower on the level of interaction.

In the next turn, the follower displays divergent interactional alignment as well, by ignoring Ana's attempts to change the subject. She explicitly labels the girls as 'Polish' and negatively evaluates their language practices by using the offensive English exclamative 'Fuck logic' in line 8. The phrase fuck logic has a history in online communication. It is both a meme series and a hash-tag used to depict and describe highly absurd and improbable phenomena. The rich intertextuality of the phrase fortifies the follower's negative evaluation of Ana's use of Norwegian (for a discussion of intertextuality in mobile communication see Deumert, 2014: 77 99). The follower denaturalizes Viola and Ana's practices by implying that it is against logic that people of Polish origins should use a language other than Polish when communicating with each other. Thus, the follower disaligns with Ana regarding the evaluation of the use of Norwegian between people of Polish origin and regarding her wish to change the subject of the conversation. However, the follower seems to be aligning with Ana on the level of style and structure by mirroring her use of English at the end of the turn (line 8). Interestingly, while speaking Norwegian between Poles is clearly not acceptable according to the follower, the use of English does not seem to be equally alarming - the follower succumbs to using an English phrase at the end of the turn, thus displaying contradictory language ideologies and practices. The follower's lack of opposition towards the use of English might mirror the language hierarchies in Poland where English enjoys a high symbolic value and prestigious status (cf. Kasztalska, 2014; Śliwa, 2010). It is also worth noting that despite the rather restrictive and conservative orientation towards the language choice in communication between Polish people, the follower does not seem to align with the 'standard language ideology’ (Lippi-Green, 1994) and does not use Polish diacritic signs in their turns.

Ana does not object to being positioned as a 'Polish girl' and in her response in line 9 , she continues with the defence, this time explicitly evaluating her and Viola's skills in Norwegian as superior through the use of the verb 'to know' in second person plural (znamy) with the adverbial of manner 'better' (lepiej). She disaligns with the follower on the level of ideology by suggesting that language practices are direct results of one's language competence rather than of national background. She closes the conversation in line 10 with a dismissive English exclamative phrase (fuck it all) and thereby sticks to the style and structure of the three previous turns. 


\section{DISCUSSION AND CONCLUSIONS}

The above conversations regarding Ana's online and offline language practices reveal strong ideological tensions and display instances of divergent alignment between Ana and her followers. The followers view Ana's use of Norwegian for communication with her Polish friends living in Norway as a questionable practice. They evaluate it negatively by invoking feelings of shame and using offensive lexicon. From the point of view of Ana's followers, language practices are directly related to ethnic belonging and national identity. This way of thinking is in line with one nation one language ideology (cf. Anderson, 1991; Woolard, 1998; Woolard \& Schieffelin, 1994), in which ethnic origins index normative language practices. Along these lines, it is anticipated that Polish should be the default language of communication between people of Polish origin, while other languages, such as Norwegian, are seen as illegitimate. A violation of these ideological expectations, i.e. in Ana's case speaking Norwegian to other Poles, is viewed as a breach of moral orders and is evaluated as 'unnatural' and reprehensible. Through metasociolinguistic stancetaking towards Ana and Viola's language practices, the followers claim a position of authority which allows them to make judgments on other people's language use. By doing so, they construct patriotic personas for themselves and at the same time position Ana and Viola as people lacking pride and respect for their origins and essentially lacking in 'Polishness'. As Duchêne \& Heller (2012) note, pride of membership and respect for national symbols (including language) are 'essential dimensions of inhabiting nation-state versions of what Bourdieu referred to as habitus' [5]. In the extracts above, Ana's followers speak precisely from these positions embedded in the nation-state oriented discourses of patriotism and national pride stemming from the local Polish discourses.

Ana, on the other hand, sees her own language practices as resulting from ease and convenience of communication, which in turn stem from language competence. Her Polish origin does not constrain her language practices and she is free to make use of any linguistic resources that will facilitate communication, as illustrated for example through her use of English in excerpt 2. Thus, speaking Norwegian is a completely normal and neutral choice for Ana when talking to other Polish teenagers living in Norway. Nevertheless, in the first excerpt, Ana attempts to establish affiliation and in-groupness with the follower through constructing Polish as a secret, common code for people who are proficient in it. Interestingly, in both excerpts Ana takes a defensive position and does not contest positions assumed by her interactants. What is more, she seems to interpret the followers' questions as challenges to her language practices and as attempts of language policing, not as genuine questions about her language practices. This could be a sign that both Ana and her followers are embedded in and constrained by the same Polish national discourses. Throughout the conversations, Ana accepts to be classified as a 'Polish girl', however, at the same time she positions herself as a legitimate and proficient user of Norwegian and as a pragmatically oriented multilingual whose language choices are not related to patriotic obligations but to perceived ease and efficiency of communication. By actively advocating for her right to use various linguistic resources, Ana contests the deterministic language ideologies (re)produced by her followers and 
constructs a flexible multilingual identity for herself and other Polish migrant adolescents in Norway. It is precisely this identity expressed indirectly through Ana's language practices that transgresses the ideological presumptions of her followers and is the cause of divergent alignment between the interactants.

This article investigated metasociolinguistic stancetaking on ASKfm platform by a Polish teenager based in Norway and her homeland-based followers. In particular this paper looked into how the interactants on ASKfm platform evaluated the use of Polish and Norwegian by migrant Polish youth living in Norway and, how in doing so, they positioned themselves and others while engaging in metalinguistic talk online. Through the application of the concept of stance, I investigated how, in talking about language practices online, the interactants (re)produced and contested language ideologies and, at the same time, constructed, ascribed and rejected identities. The analysis showed that Ana's followers displayed essentialist views on language use and identity, whereby they constructed indexical links between nationality and restrictive language practices. The focal participant disaligned with the followers, contested the language ideologies put forward by them and advocated an unrestricted and flexible use of linguistic resources which does not index nationality nor belonging and instead results from the situated ease and convenience of communication. Empirically, the paper provided evidence of ASKfm's potential as a stancerich online research site and showed that online platforms may function as a window into the transnational interactions between diasporas and the homeland-based societies. Theoretically, the paper contributed to the growing body of literature on stancetaking online and stressed the usefulness of the concept of metasociolinguistic stancetaking for examining how identities are ascribed, constructed and rejected through (re) producing and contesting language ideologies in metalinguistic talk.

\section{ACKNOWLEDGEMENTS}

I would like to thank my PhD supervisors Professor Bente Ailin Svendsen and Professor Ana Deumert, as well as Doctor Nathan Albury for their feedback on earlier drafts of this article.

\section{FUNDING}

The writing of this paper was supported by the Research Council of Norway through its Centres of Excellence funding scheme, project number 223265 (MultiLing) and 240725 (MultiFam).

\section{REFERENCES}

Anderson, B. 1991 . Imagined Communities: Reflections on the Origin and Spread of Nationalism. Verso.

Androutsopoulos, J. 2008 . Potentials and Limitations of Discourse-Centred Online Ethnography. Language@ Internet 5(8). Retrieved from http:// www.languageatinternet.org/ articles/2008/1610

Androutsopoulos, J. 2015 . Networked multilingualism: Some language practices on Facebook and their implications. International Journal of Bilingualism 19(2), 185-205.

Barton, D., \& Lee, C. 2013 . Language Online: Investigating Digital Texts and Practices. Routledge.

Bell, J., \& Erdal, M. 2015 . Limited but Enduring Transnational Ties? Transnational Family Life Among Polish Migrants in Norway. Studia Migracyjne Przegląd Polonijny 157(3), 77-98.

Biber, D., \& Finegan, E. 2009 . Styles of stance in English: Lexical and 
grammatical marking of evidentiality and affect. Text - Interdisciplinary Journal for the Study of Discourse 9(1), 93-124.

Bonilla-Silva, E. 2002. The Linguistics of Color Blind Racism: How to Talk Nasty about Blacks without Sounding "Racist." Critical Sociology 28(1-2), 41-64.

Brown, P., \& Levinson, S. C. 1987. Politeness: Some Universals in Language Usage. Cambridge University Press.

Bygdås, M. E. 2016 . Fra Warszawa til Oslo: Språkvalgog identiteterhos polsk-norske ungdommer. Unpublished Master Thesis.

Chłopicki, W. 2005. Polish under siege? In G. M. Anderman \& M. Rogers (Eds.), In and out of English: For better, for worse . 108-122.

Chun, E., \& Walters, K. 2011. Orienting to Arab Orientalisms: Language, Race, and Humor in a YouTube Video. In Digital Discourse. Oxford University Press.

Cieśla, J. 2012. Polski patriotyzm w oczach Polaków. Retrieved February 13, 2017, from http:// www.polityka.pl/tygodnikpolityka/ spoleczenstwo/1524253,1,polskipatriotyzm-w-oczach-polakow.read

De Fina, A. 2003. Identity in Narrative: A study of immigrant discourse (Vol. 3). Amsterdam: John Benjamins Publishing Company.

Deumert, A. 2014. Sociolinguistics and Mobile Communication. Edinburgh University Press.

Du Bois, J. W. 2007. The stance triangle. In R. Englebretson (Ed.), Pragmatics $\mathcal{E}^{\circ}$ Beyond New Series 164, pp.139-182. Amsterdam: John Benjamins Publishing Company.

Duchêne, A., \& Heller, M. 2012. Language in Late Capitalism: Pride and Profit. Routledge.

Duszak, A. 2006. Why 'New' Newspeak? Axiological Insights into Language Ideologies and Practices in Poland. In C. Mar-Molinero \& P. Stevenson (Eds.), Language Ideologies, Policies and Practices: Language and the Future of Europe. . 91-103. Houndmills and New York: Palgrave Macmillan.
Gal, S., \& Irvine, J. T. 2000. Language ideology and linguistic differentiation. In P. V. Kroskrity (Ed.), Regimes of Language: Ideologies, Polities, and Identities. pp.35-84. Santa Fe: School of American Research Press.

Hoffman, M. 2013 . Sociolinguistic Interviews. In J. Holmes \& K. Hazen (Eds.), Research Methods in Sociolinguistics: A Practical Guide. John Wiley \& Sons.

Jaffe, A. 2009. Stance: Sociolinguistic Perspectives. Oxford University Press.

Jaworski, A., Coupland, N., \& Galasiński, D. 2004 . Metalanguage: Social and Ideological Perspectives. Bod Third Party Titles.

Johnstone, B. 2009. Stance, Style, and the Linguistic Individual. In A. Jaffe (Ed.), Stance: Sociolinguistic Perspectives. Oxford, New York: Oxford University Press.

Jones, G., Schieffelin, B., \& Smith, R. 2011. When Friends Who Talk Together Stalk Together: Online Gossip as Metacommunication - Oxford Scholarship. In Digital Discourse: Language in the New Media. 26-47.

Kasztalska, A. 2014. English in contemporary Poland. World Englishes 33(2), 242-262.

Kroskrity, P. V. 2010. Language ideologies - Evolving perspectives. In J. Jaspers, J. Verschueren, \& J.-O. Östman (Eds.), Society and Language Use. 192-211.

Leszczyński, A. 2016. Niepodległościowi lewacy. Spór o polski patriotyzm. Retrieved February 13, 2017, from http:// wyborcza.pl/alehistoria/1,121681,1955 9464,niepodleglosciowi-lewacy-spor-opolski-patriotyzm.html

Lippi-Green, R. 1994. Accent, Standard Language Ideology, and Discriminatory Pretext in the Courts. Language in Society 23(2), 163-198.

Myers, G. 2010. Stance-taking and public discussion in blogs. Critical Discourse Studies, 7(4), 263-275.

Newsweek Polska. 2014, March 19. W Newsweeku: Sorry, Polsko. Co dla nastoletnich Polaków oznacza patriotyzm? Retrieved February 13, 2017, from http://www.newsweek.pl/polska/ 
patriotyzm-co-oznacza-dla-mlodychpolakow-,artykuly,282392,1.html

Pavlenko, A., \& Blackledge, A. 2004. Negotiation of Identities in Multilingual Contexts. Multilingual Matters.

Slany, K., \& Strzemecka, S. 2015. Gender Roles and Practices in Polish Migration Families in Norway through the Eyes of Children. Studia Migracyjne - Przeglad Polonijny 157(3), 157-181.

Śliwa, M. 2010. "Catching up with "civilisation"': reflections on language spread in Poland. Journal of Organizational Change Management 23(6), 689-709.

Statistics Norway. 2016. Nearly 10000 Syrian immigrants in Norway. Retrieved July 28, 2016, from http://www.ssb. no/en/befolkning/statistikker/innvbef/ aar/2016-03-03

Thurlow, C., \& Jaworski, A. 2009. Taking an elitist stance: Ideology and the discursive production of social distinction. In A. Jaffe (Ed.), Stance. Sociolinguistic perspectives pp.195-226. New York: Oxford University Press.
Vandergriff, I. 2016. Second-language Discourse in the Digital World: Linguistic and social practices in and beyond the networked classroom. John Benjamins Publishing Company.

Wærdahl, R. 2016. The Invisible Immigrant Child in the Norwegian Classroom: Losing Sight of Polish Children's Immigrant Status Through Unarticulated Differences and Behind Good Intentions. Central and Eastern European Migration Review 5, 1-16.

Walton, S., \& Jaffe, A. 2011. "Stuff White People Like": Stance, Class, Race, and Internet Commentary. In Digital Discourse. Oxford University Press.

Woolard, K. A. 1998. Language ideology as a field of inquiry. In K. A. Woolard, B. Schieffelin, \& P. Kroskrity (Eds.), Language Ideologies: Practice and theory. New York: Oxford University press.

Woolard, K. A., \& Schieffelin, B. B. 1994. Language Ideology. Annual Review of Anthropology 23(1), 55-82. 